\title{
Implementation of DC Motor PID Control on Conveyor for Separating Potato Seeds by Weight
}

\author{
Daniya Sonny Febriyan a,1, , Riky Dwi Puriyanto a,b,2 \\ ${ }^{a}$ Universitas Ahmad Dahlan, Yogyakarta, Indonesia \\ ${ }^{\mathrm{b}}$ Universitas Gadjah Mada, Yogyakarta, Indonesia \\ ${ }^{1}$ sonnyfebriyan56@gmail.com; ${ }^{2}$ rikydp@ee.uad.ac.id \\ * Corresponding Author
}

\section{ARTICLE INFO}

Article history

Received 28 January 2021

Revised 15 February 2021

Accepted 21 February 2021

Keywords

Benih Kentang;

Pemilah Benih;

Conveyor;

Kontrol PID;

Arduino

\begin{abstract}
Dieng area is a mountainous area, dieng has land with high fertility levels so that they are increasingly high in the agricultural sector, especially potatoes. During the time, the technology for sorting potato seeds was still manual with humans, so it was less effective. The conveyor here is very useful as this device which will later work with loadcell as a weigher, and this device will be driven using a dc motor then the speed stabilization uses the PID algorithm with trial and error methods and this tool is supported using ultrasonic sensors and two servo sorting. This device works with 1 cycle, namely with 1 command with a value of KP 55, KI 20 and KD 0.001 . The conveyor movement is quite stable with an average error value of 0.276 load cell with a standard deviation of 0.211877 with an achievement level of $80 \%$.
\end{abstract}

This is an open access article under the CC-BY-SA license.

\section{Pendahuluan}

Kawasan dieng yang merupakan pegunungan yang dahulunya pernah beberapa kali meletus. Hal itu mengakibatkan tanah yang ada di pegunungan dieng tingkat kesuburannya tinggi, maka dari itu mayoritas penduduk kawasan dieng mata pencahariannya adalah bercocok tanam atau bertani salah satunya kentang. Kentang menjadi salah satu yang paling banyak di tanam, akan tetapi hasil panen kentang dieng belum cukup maksimal hal itu dikarenakan ada beberapa faktor yang mempengaruhi salah satunya adalah pemilihan benih kentang. Berdasarkan data yang diperoleh di lapangan, sebagian petani mengatakan bahwa bibit kentang yang baik digunakan sebagai benih yaitu dari indukan awal tanamannya yang kedua yaitu dilihat dari ukurannya yaitu berukuran $>100 \mathrm{gr}$.

Pemilihan benih berdasarkan berat yang dilakukan masyarakat dieng pada umunya menggunakan pemisahan manual dengan tangan. Berat yang ditentukan yaitu berdasarkan pada rabaan tangan, sehingga kurang akurat dan harus menempatkan benih kentang tersebut beberapa tempat sesuai dengan berat rabaan tangan pemilihnya. Maka dari itu dibutuhkannya suatu terobosan alat yang nantinya dapat digunakan sebagai pemilah dan juga pengantar benih 
pada tempatnya kemudian dibuatlah penelitian yang berjudul Implementasi Kendali PID pada Konveyor Pemisah Bibit Kentang Berdasarkan Berat.

Berdasarkan masalah yang ada, peneliti mengumpulkan data dari beberapa sumber yang berkaitan dengan penelitian ini. Akhirudin pada Tahun 2017 meneliti yang berjudul Perancangan Alat Pemisah dan Penyortir Buah Jeruk Berbasis Arduino dengan menggunakan metode Arduino sebagai pusat pengendali pengendalinya. Alat ini menggunakan Arduino sebagai pengendali, penggerak menggunakan motor DC lalu beban akan berjalan melewati sensor dan motor servo akan memilah berdasarkan volume untuk di identifikasi harga [1].

Pada Tahun 2019 Ahmadan Ainul Fikri meneliti yang berjudul Sistem Pengaturan PID Motor DC Sebagai Penggerak Mini konveyor Berbasis Matlab Penelitian ini menggunakan metode analitic sehingga didapatkan respon riil motor dan mendapatkan nilai $\mathrm{kp}=0,94624747$, $\mathrm{ki}=51,4023958$ dan $\mathrm{kd}=0,01941504$ [2]. Sistem kendali PID untuk pengendalian kecepatan motor penggerak unmanned ground vehicle untuk aplikasi industri pertanian yang diteliti Widagdo Purbowaskito dan Chung-Hao Hsu mengatakan sistem perancangan kendali ini diperuntukkan bagi sebuah robot UGV, Sistem kendali untuk mengendalikan kecepatan sudut motor dc pada roda penggerak UGV telah dirancang menggunakan PID dengan metode trial and error dan didapatkan nilai $\mathrm{kp}=0,03 ; \mathrm{ki}=0 ; 0000001$; dan $\mathrm{kd}=0,005$ [3].

Selanjutnya pada tahun 2015 Joko Prasetyo, Dkk melakukan penelitian yang berjudul Uji Performasi Pada Sistem Kontol Level Air Dengan Variasi Beban menggunakan Kontroler PID. Penelitian ini menggunakan metode Ziegler-Nichols untuk mendapatkan nilai parameter kontroler PID dan telah menggunakan nilai formula anjuran dari Ziegler-Nichols itu sendiri [4]. Selanjutnya Mohamad Nadhif dan Suryono meneliti dengan judul Aplikasi Fuzzy Logic untuk Pengendalian Motor DC Berbasis Mikrokontroler ATMega8535 dengan Sensor Fotodiode, Sistem logika Fuzzy dengan mikrokontroler ATMega8535 dan menggunakan sensor fotodiode dapat mengontrol kecepatan putar motor dc. Dengan cara pembentukan himpunan Fuzzy, aplikasi fungsi implikasi pada metode Mamdani, komposisi antara aturan dan penegasan (deFuzzy) [5].

Pada penelitian selanjutnya yaitu dilakukan oleh Zaidir Jamal yang meneliti tentang implementasi kendali PID penalaan Ziegler-Nichols menggunakan mikrokontroler. Penelitian ini menggunakan metode tuning Ziegler-Nichols dan sangat baik hasilnya karena overshoot yang terjadi $1 \mathrm{~cm}$ atau 0,05\% rise time menunjukkan 280 detik dan IAE rata-rata 3,1733 [6]. Selanjutnya ada penelitian yang berjudul Aplikasi Metode Cerdas Untuk Optimasi Controller PID Motor DC Berbasis Firefly algorithm oleh Muhammad Ruswandi Djalal dkk, algoritma ini pertama ditemukan oleh Xin-She Yang di Universitas Cambridge pada tahun 2007, Penelitian ini sebenarnya tentang perbandingan Firefly, bee colony dan cuckoo algorithm sebagai penalaan parameter nilai PID dengan hasil yang sangat optimal dimana setting time sangat cepat dibandingkan dengan yang lain [7].

Ada juga penelitian yang berjudul Kecepatan Motor DC Menggunakan Perintah Suara Berbasis Mikrokontroler, pada penelitian ini pengaturan kecepatan motor dc yang dilakukan hanya dengan mengubah besar tegangan masukan ke motor, sehingga mempunyai keterbatasan di dalam pengaturan kecepatan yang melebihi nominalnya [8]. Kemudian ada penelitian yang berjudul Kecepatan Motor DC pada Aplikasi Belt konveyor Menggunakan Logika Fuzi berbasis mikrokontroler, penggunaan algoritma logika Fuzi sebagai metode pada pengendalian kecepatan konveyor secara otomatis dapat menjaga agar kecepatan konveyor tersebut dalam kecepatan normal [9].

Yang terakhir ada penelitian yang berjudul Sistem Pengalihan Arah Konveyor Pada AGV Conveyor Diverting System On AGV, penelitian ini menghasilkan rata-rata pembacaan sensor 
fotodiode ketika mendeteksi warna hitam dan putih adalah 750 dan 46 yang sudah memiliki rentang yang cukup jauh sehingga diperoleh nilai threshold rata-rata 404. Selain pembacaan sensor fotodiode, hasil pembacaan RFID juga diperlukan agar AGV dapat berhenti tepat pada terminal barang dengan jarak pemasangan RFID reader $3 \mathrm{~cm}$ dengan RFID tag dimana kondisi AGV sedang bergerak. Tingkat keberhasilan dari 8 kali pengujian adalah 75\% dengan 6 kali berhenti tepat pada terminal dan 2 kali berhenti tidak tepat pada terminal [10].

Berdasarkan penelitian sebelumnya selanjutnya peneliti mengusulkan membuat konveyor dengan kontrol PID. Alat ini nantinya akan dirancang sedemikian rupa supaya dapat memilah benih kentang. Pemilahan ini mengategorikan berdasarkan berat dengan sistem pemilihnya menggunakan motor servo yang dikendalikan oleh sensor jarak. Pada arah perputaran motor, peneliti menggunakan algoritma PID dengan metode trial and error.

\section{Proportional, Integral \& Derivative Controller}

Dalam suatu sistem kendali otomatis terdapat juga metode-metode yang mungkin dapat digunakan untuk menentukan nilai parameter PID antara lain Evolusi Diferensial, Algoritma genetik, Particle Swarm Optimization (PSO) [11], dan Trial and error dan masih banyak lagi metode-metode yang bisa digunakan.

\subsection{Diagram Blok Sistem Kendali}

Perancangan sistem pertama seperti yang ditampilkan pada Gambar 1 yaitu dari sumber $5 \mathrm{~V}$ dihubungkan langsung dengan Arduino, kemudian sensor berat dihubungkan dengan modul HX711 sebagai masukan pertama lalu ada sensor jarak menjadi input dan mengeluarkan output berupa motor servo 1. Dari data sensor berat yang ditampilkan pada LCD maka data akan diolah pada Arduino dan dikirimkan pada servo dan mengirimkan data output sebagai pemisah.

Gambar 2 yaitu sistem pada penggerak, pada catu daya 12V dihubungkan ke driver yang menghubungkan ke motor DC, dan sebagai masukan pembacaan/pengontrol putaran menggunakan encoder dengan tegangan $3 \mathrm{~V}$ yang dihubungkan ke Arduino dan dikirimkan kembali dalam bentuk keluaran putaran motor.

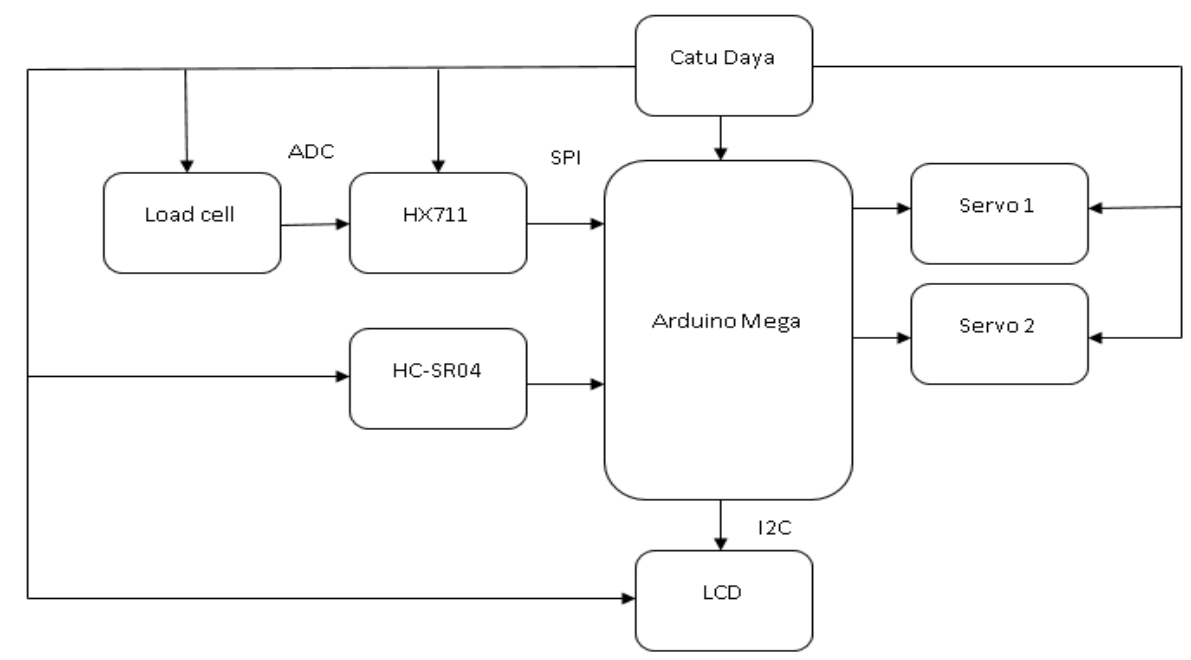

Gambar 1. Diagram Blok Pemisah

\subsection{Metode PID Trial and Error}

Metode ini adalah metode yang paling banyak digunakan karena pencarian nilai yang digunakan secara acak untuk mendapatkan nilai PID yang sesuai. Metode ini biasa di 
aplikasikan pada PLC maupun mikrokontroler lainya seperti Arduino dikarenakan rumus dari metode ini sangat lah mudah dan banyak referensi yang membahas tentang metode ini. Metode ini memiliki kelemahan di antaranya yaitu dibutuhkan waktu yang cukup lama untuk menstabilkan ketiga pengendali ini karena peneliti diharuskan mencari angka satu-persatu itu dikarenakan nilai dari parameter ini tidak independen [12]. Namun pada suatu keadaan nilai parameter ini tidak bekerja bersama namun hanya beberapa nilai parameter pengendalinya saja yang digunakan.

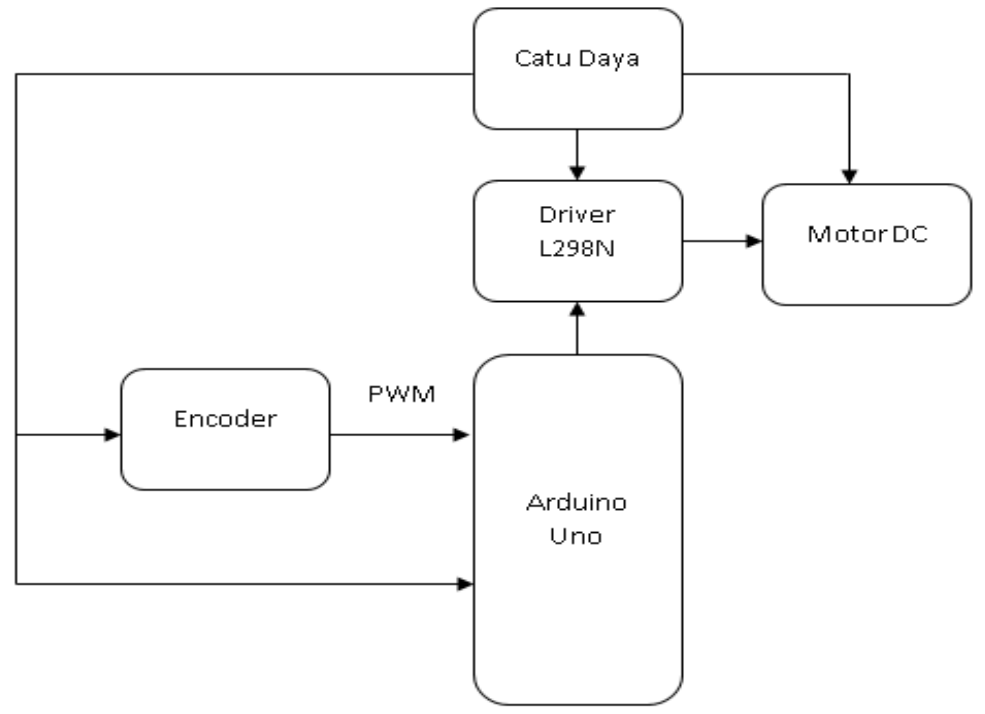

Gambar 2. Diagram Blok Motor Encoder

\section{Metode}

\subsection{Desain Sistem}

Desain alat ditunjukkan pada Gambar 3. Sistem ini dijalankan dengan menggunakan dua Arduino yaitu Arduino mega dan Arduino Uno. Sistem penyortir kentang dirancang dan dibuat dengan menggunakan mikrokontroler Arduino mega dan Arduino Uno sebagai pengendali motornya. Perangkat terdiri atas Software Arduino 1.6.10, sensor HC-SRF04, sensor berat (Loadcell), HX711, motor DC, motor servo, L298N, loadcell dan komponen pendukung lainnya.

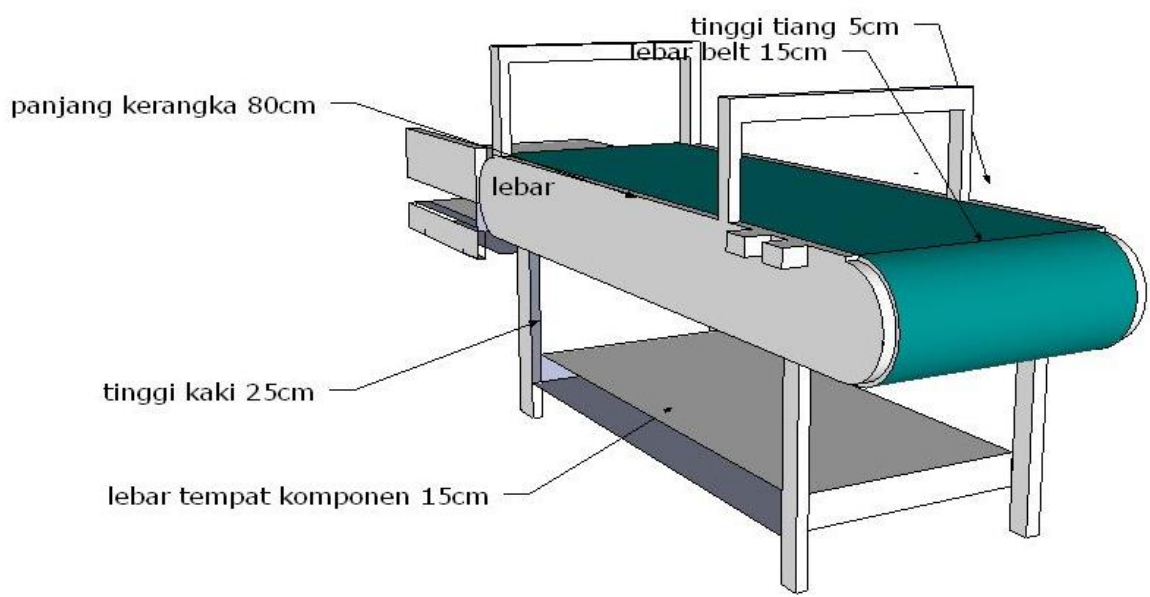

Gambar 3. Desain Konveyor 


\subsection{Diagram Pengkabelan}

Diagram pengkabelan pada penelitian kali ini dipisah antara pengendalian motor dengan pengendalian sistem pemilihnya. Gambar 4 menampilkan diagram pengkabelan pengendalian motornya. Tabel 1 menampilkan PIN input/output yang digunakan. Gambar 5 menampilkan diagram pengkabelan sistem pemilihnya. Tabel 2 menampilkan PIN keluaran dan masukan dari sensor dan mikrokontroler.

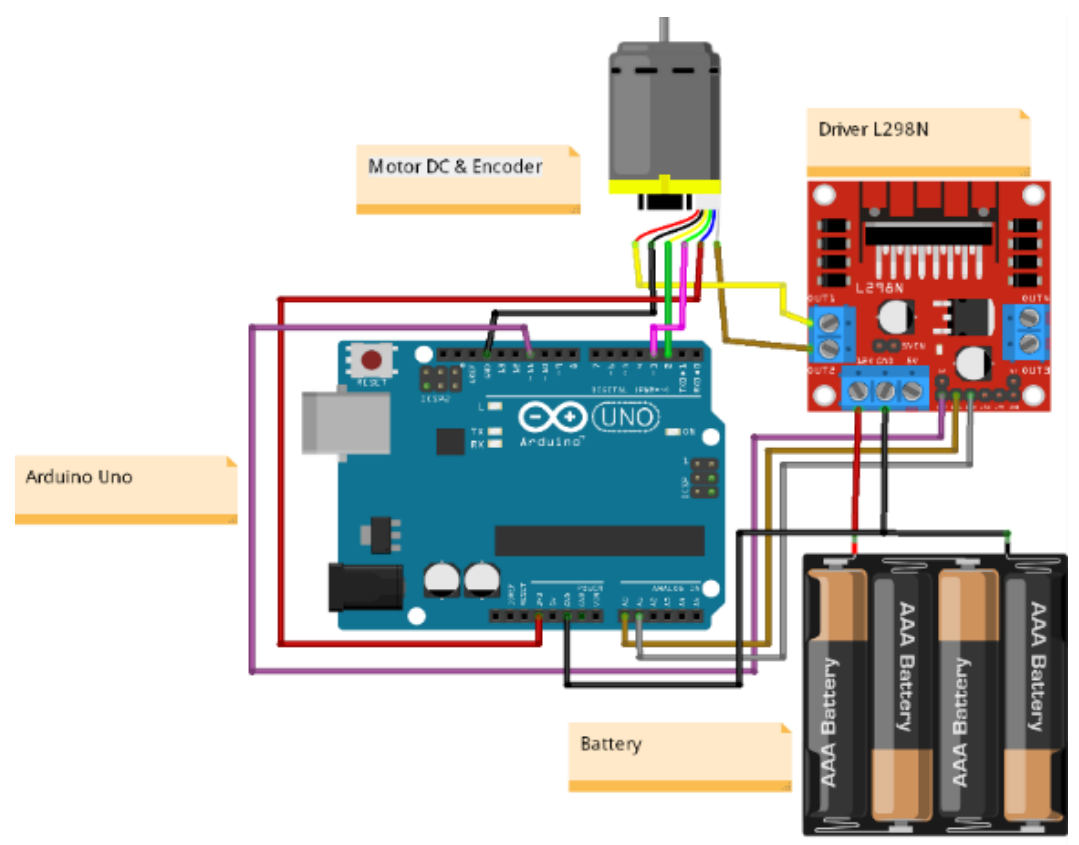

Gambar 4. Wiring Diagram Motor DC

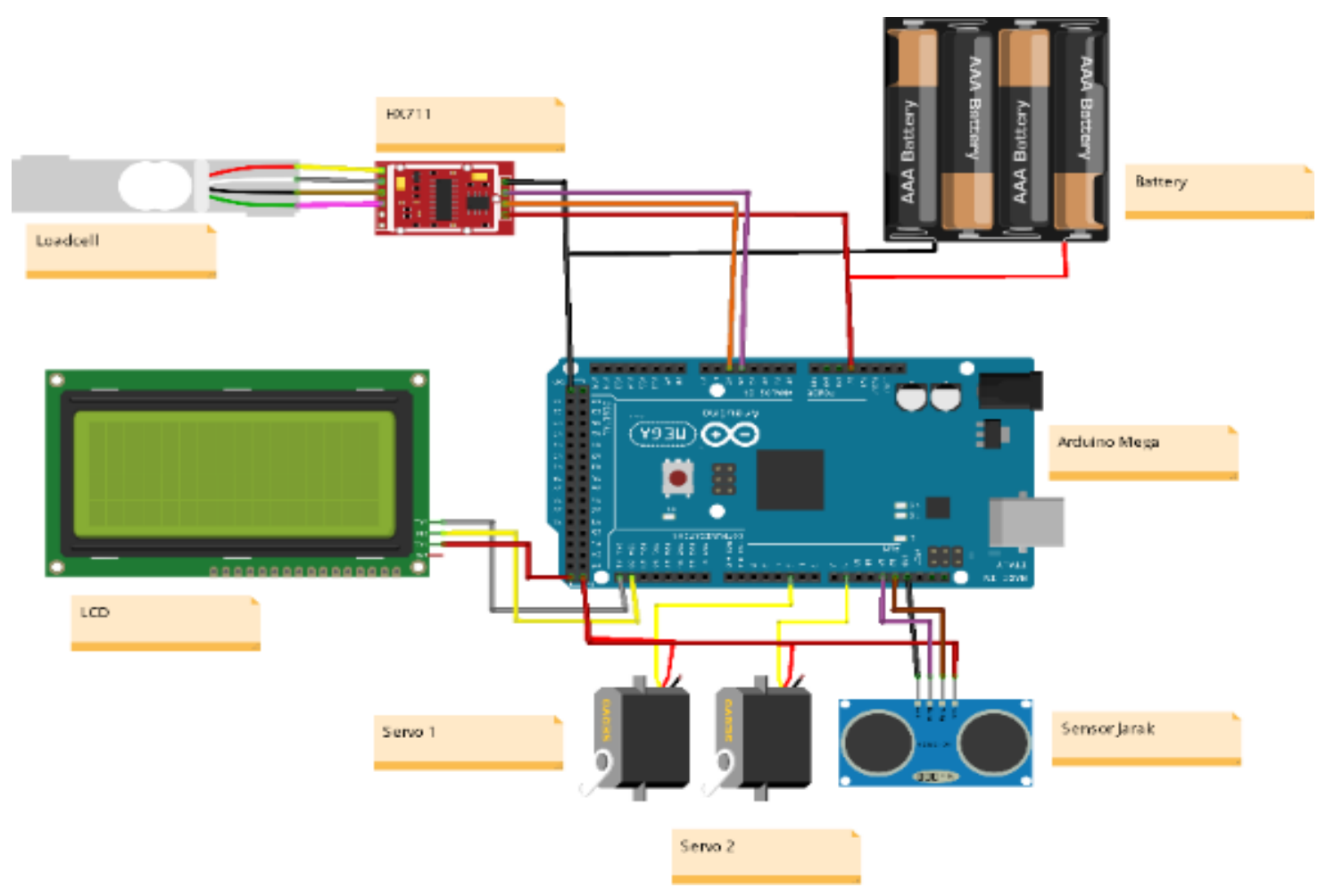

Gambar 5. Diagram Pengkabelan Sensor Pemisah 
Tabel 1. Pin I/O Pengendali

\begin{tabular}{|c|c|c|c|}
\hline \multirow{2}{*}{ No } & \multicolumn{3}{|c|}{ Pin } \\
\cline { 2 - 4 } & \multicolumn{2}{|c|}{ Komponen } & Arduino Uno \\
\hline \multirow{4}{*}{1} & Encoder & GND & GND \\
\cline { 3 - 4 } & & $3,3 \mathrm{~V}$ & $3,3 \mathrm{~V}$ \\
\cline { 3 - 4 } & & $\mathrm{C} 1$ & 2 \\
\cline { 3 - 4 } & \multirow{2}{*}{ Driver L298N } & $\mathrm{C} 2$ & 3 \\
\cline { 3 - 4 } & & $\mathrm{In} 0$ & $11(\mathrm{PWM})$ \\
\cline { 3 - 4 } & & $\mathrm{In} 2$ & $\mathrm{~A} 0$ \\
\hline \multirow{2}{*}{3} & \multirow{2}{*}{ Motor DC } & $\mathrm{GN} 1$ \\
\cline { 3 - 4 } & & $\mathrm{M} 1$ & GND \\
\cline { 3 - 4 } & & Out 1 \\
\hline
\end{tabular}

Tabel 2. Pin I/O Sensor

\begin{tabular}{|c|c|c|c|}
\hline \multirow[t]{2}{*}{ No } & \multicolumn{3}{|c|}{ Pin I/O } \\
\hline & \multicolumn{2}{|c|}{ Sensor } & Arduino \\
\hline \multirow[t]{4}{*}{1} & \multirow[t]{4}{*}{ HC-SR04 } & Trig & 13 \\
\hline & & Echo & 12 \\
\hline & & VCC & $5 \mathrm{~V}$ \\
\hline & & GND & GND \\
\hline \multirow[t]{3}{*}{2} & \multirow[t]{3}{*}{ Servo 1} & Input & 9 \\
\hline & & VCC & $5 \mathrm{~V}$ \\
\hline & & GND & GND \\
\hline \multirow[t]{3}{*}{3} & \multirow[t]{3}{*}{ Servo 2} & Input & 5 \\
\hline & & VCC & $5 \mathrm{~V}$ \\
\hline & & GND & GND \\
\hline \multirow[t]{4}{*}{4} & \multirow[t]{4}{*}{ LCD I2C } & VCC & VCC \\
\hline & & SDA & SDA \\
\hline & & SCL & SCL \\
\hline & & GND & GND \\
\hline \multirow[t]{4}{*}{5} & \multirow[t]{4}{*}{ HX711 } & GND & GND \\
\hline & & DT (output data) & A4 \\
\hline & & SCK (Serial komunikasi SPI) & A5 \\
\hline & & VCC & $5 \mathrm{~V}$ \\
\hline \multirow[t]{4}{*}{6} & \multirow[t]{4}{*}{ Loadcell } & Merah & Input $(\mathrm{E}+)$ \\
\hline & & Hitam & Output(E-) \\
\hline & & Hijau & Input(A-) \\
\hline & & Putih & Output $(\mathrm{A}+)$ \\
\hline
\end{tabular}

\subsection{Algoritma}

Cara kerja alat ini yaitu konveyor tetap berjalan kemudian sensor ultrasonik mendeteksi beban yang ada pada loadcell, kemudian akan memberikan perintah kepada servo 1 untuk mengubah sudut untuk mendorong beban ke konveyor, kemudian jika beban $>100 \mathrm{gr}$ maka perintah yang disampaikan ke servo 2 yaitu menutup palang sebagai pemisahnya, dan jika beban <100gr maka perintah yang dikirimkan kepada servo yaitu tetap pada posisinya dan membiarkan beban lewat, pengujian sistem ini dapat dilihat pada flowchart yang ditampilkan pada Gambar 6. 


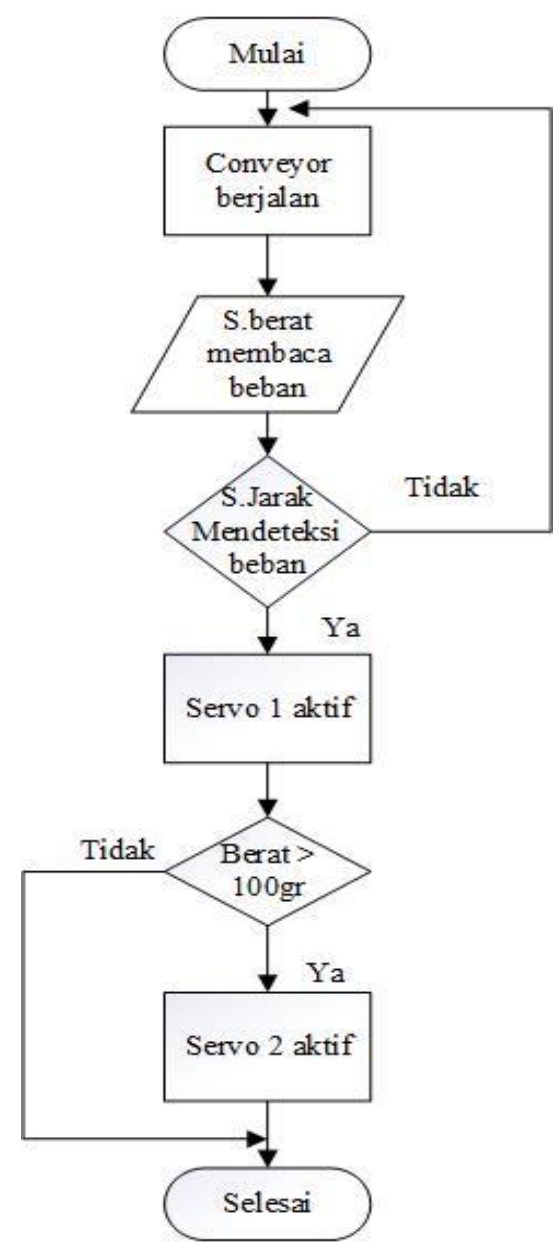

Gambar 6. Diagram Alir (Flowchart)

\section{Hasil dan Pembahasan}

Hasil desain sistem berupa perangkat keras ditunjukkan pada Gambar 7. Pada bagian ini alat tersebut akan diuji dan dianalisis untuk mengetahui kinerja sistem.

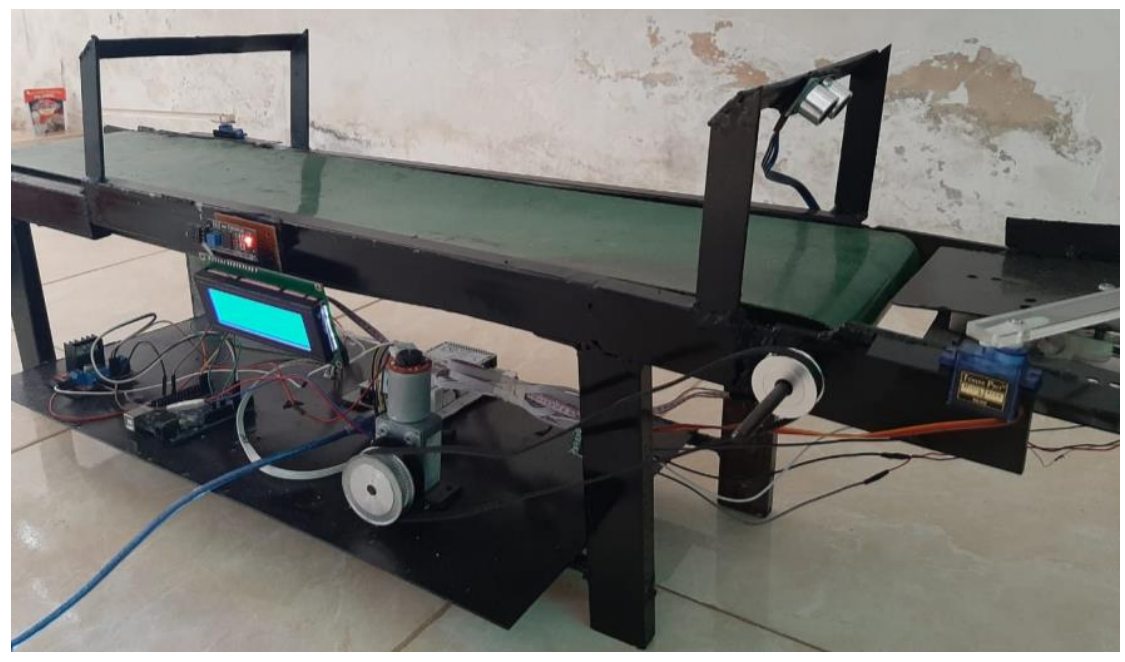

Gambar 7. Hasil Desain Sistem 


\subsection{Pengujian Nilai PID}

Pengujian ini yaitu memasukkan nilai KP, KI dan KD secara terpisah sehingga berdasarkan nilai tersebut yang nantinya akan diimplementasikan ke motor DC yang digunakan sebagai penggerak konveyor, yang akan ditampilkan dengan bentuk grafik Gambar 8.

Berdasarkan grafik yang ditampilkan pada Gambar 8 nilai KP bernilai 25 dan 75. Pengujian dengan nilai set poin 90RPM, kedua nilai ini tidak ada yang berhasil mencapai set poin. Berbeda dengan nilai KP 80, respon yang didapatkan yaitu melebihi set poin. Oleh karena itu respon yang ditampilkan nilai 80 adalah nilai yang paling sesuai dengan penelitian yang dilakukan.

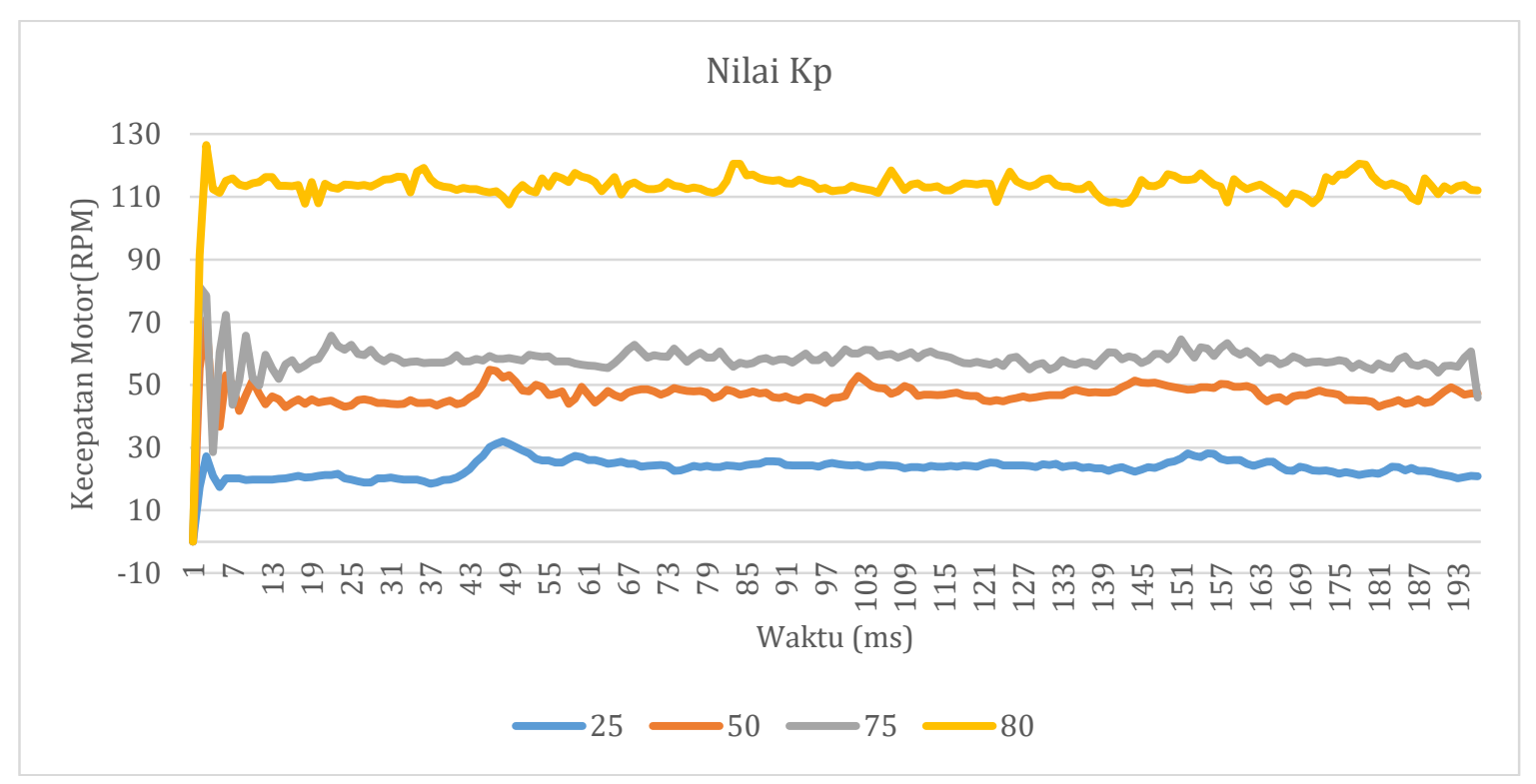

Gambar 8. Grafik nilai KP

Berdasarkan grafik Gambar 9 yaitu menampilkan dari nilai KI. Nilai KI yang paling sesuai yaitu 25. Hal tersebut dikarenakan respon yang ditampilkan melalui grafik pergerakan dimulai dari RPM awal terjadi jeda waktu sekitar 0,9 detik dan setelahnya pergerakan respon yang ditampilkan langsung menuju set poin yang telah ditetapkan yaitu 90RPM.

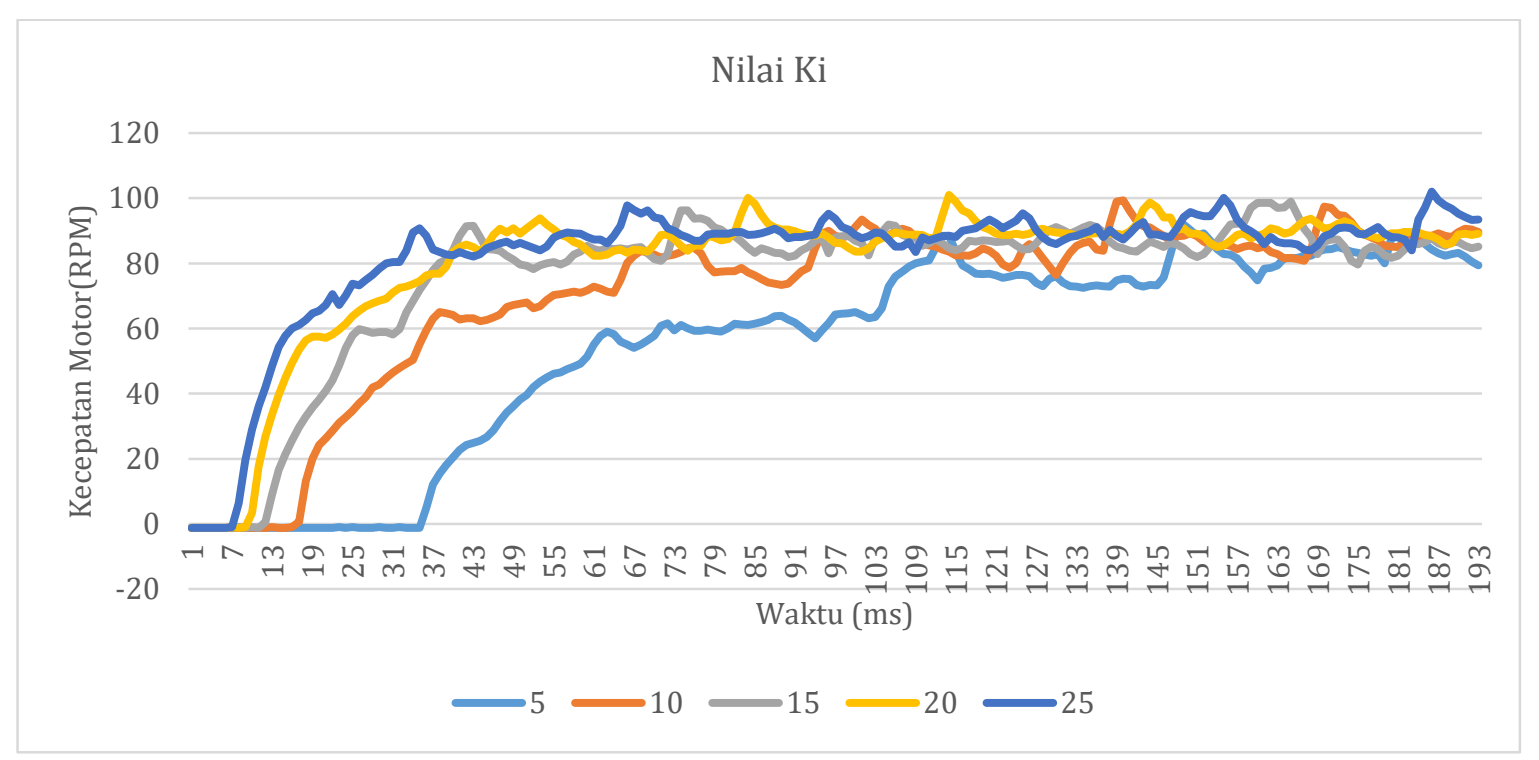

Gambar 9. Grafik nilai KI 
Hasil pengujian nilai KD yang ditampilkan pada Gambar 10 yang paling sesuai dengan penelitian ini yaitu bernilai 5. Hal tersebut dikarenakan respon yang dihasilkan cenderung stabil yaitu hanya terjadi satu kali overshoot yang jika digabungkan menjadi nilai KP, KI dan KD pergerakan awal motor cenderung lebih stabil atau halus dalam mencapai set poin.

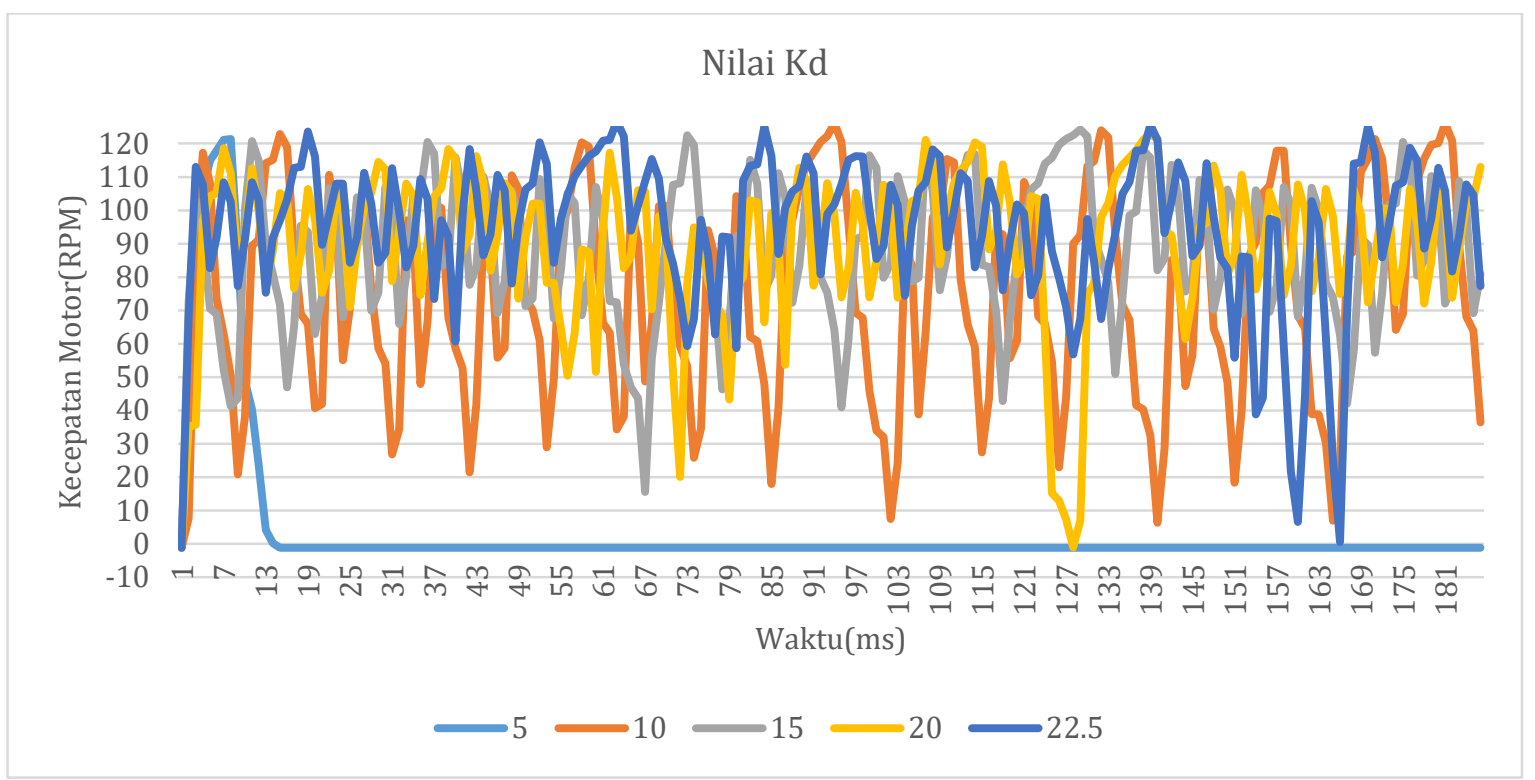

Gambar 10. Grafik nilai KD

\subsection{Pengujian Sensor}

Berdasarkan timbangan yang dibuat yaitu digital maka dalam kalibrasi terdapat pada program yang dibuat. Program yang dibuat terdapat fitur kalibrasi otomatis, peneliti hanya mengubah angka pada float $\mathrm{i}=$ (i(pembacaan sensor)*/: sesuai angka yang dibutuhkan) sehingga papan peletakan benih bernilai 0 atau nilai toleransinya mengecil. Percobaan yang pertama adalah menguji akurasi timbangan yang menjadi tolak ukur untuk memilah benih sensor ini bekerja bagian lain yang lebih elastik mendapat tekanan, sensor loadcell di sini bekerja jika bagian elastik mendapat tekanan maka akan terjadi perubahan strain gauge atau perubahan renggangan, hal ini terjadi karena adanya gaya yang saling melawan pada sisi lainya, sehingga terjadi nilai resistansi oleh perubahan gaya dan mengubah nilai tegangan pada rangkaian pengukuran yang ada. Dan berat objek yang diukur nantinya akan diketahui dengan mengukur besarnya nilai tegangan yang timbul, Gambar 11 menampilkan kompilasi yang ditampilkan pada LCD.

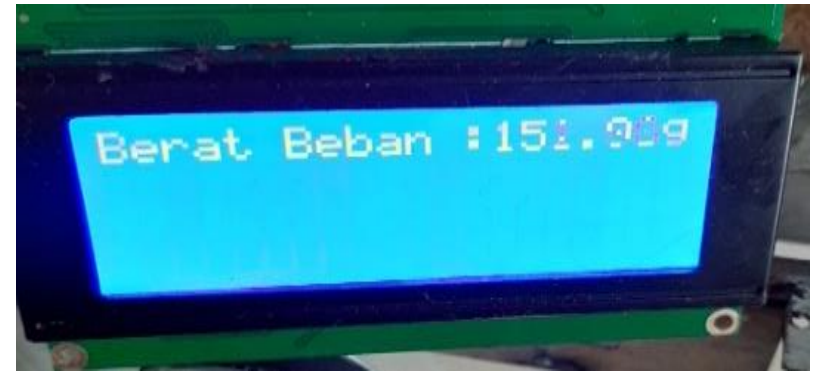

Gambar 11. Hasil pembacaan loadcell

Berikutnya adalah pengujian sekaligus sebagai kalibrasi perbandingan loadcell yang dibuat peneliti dengan pengukur berat yang dipakai secara umum antara yang sudah ada dan dijual di 
pasaran. Hasil perhitungan perbandingan dari loadcell yang dibuat dengan peneliti dan alat pengukur beban pada umumnya ditampilkan di Tabel 3.

Tabel 3. Tingkat Keberhasilan Sensor

\begin{tabular}{|c|c|c|c|}
\hline \multirow[t]{2}{*}{ No } & Loadcell(g) & Beban $\operatorname{acuan}(\mathrm{g})$ & \multirow{2}{*}{$\begin{array}{c}\text { Selisih } \\
\left(\Delta=\left|\mathbf{w}^{\text {ba }}-\mathbf{w}^{\mathrm{Lc}}\right|\right)\end{array}$} \\
\hline & $w^{\mathrm{Lc}}$ & $\mathbf{w}^{\mathbf{b a}}$ & \\
\hline Pengujian 1 & 28,22 & 28,59 & 0,37 \\
\hline Pengujian 2 & 36,84 & 37,32 & 0,48 \\
\hline Pengujian 3 & 41,642 & 41,73 & 0,088 \\
\hline Pengujian 4 & 43,938 & 44,02 & 0,082 \\
\hline Pengujian 5 & 64,97 & 65,09 & 0,12 \\
\hline Pengujian 6 & 65,878 & 66,01 & 0,132 \\
\hline Pengujian 7 & 71,818 & 71,96 & 0,142 \\
\hline Pengujian 8 & 80,32 & 80,33 & 0,01 \\
\hline Pengujian 9 & 105,16 & 105,72 & 0,56 \\
\hline Pengujian 10 & 155,32 & 155,95 & 0,63 \\
\hline Pengujian 11 & 164,43 & 164,47 & 0,04 \\
\hline Pengujian 12 & 183,41 & 183,87 & 0,46 \\
\hline Pengujian 13 & 367,68 & 367,98 & 0,3 \\
\hline \multirow[t]{3}{*}{ Pengujian 14} & 379,15 & 379,6 & 0,45 \\
\hline & & Rata-rata error & 0,276 \\
\hline & & Standar deviasi & 0,211877 \\
\hline
\end{tabular}

Berdasarkan Tabel 3 dapat dikatakan bahwa timbangan yang dibuat peneliti masih terdapat error, error yang terjadi dihasilkan dari beberapa faktor antara lain pemasangan loadcell yang kurang sesuai, ketidakseimbangan beban pada saat diletakan atau pergerakan lainya karena sensor ini membaca berdasarkan keelastisannya sehingga terjadi pergerakan sedikit saja dapat mempengaruhi nilainya yang ditampilkan dan nilai error didapat dengan cara mengurangi nilai timbangan standar dengan nilai yang tertampil pada loadcell, sehingga nilai error yang ditampilkan merupakan nilai toleransi pada loadcell yang dibuat peneliti.

\subsection{Pengujian Alat}

Setelah melakukan pengujian terhadap nilai KP, KI dan KD, berikutnya berdasarkan nilai yang telah didapatkan dan digabungkan. Grafik respon yang terjadi tidak sesuai dengan yang diharapakan sehingga peneliti mengubah sedikit berdasarkan nilai yang ada pada Gambar 7 , Gambar 8 dan Gambar 9 kemudian didapatkan nilai $\mathrm{KP}=55, \mathrm{KI}=20$ dan KD = 0,0001. Respon dapat dilihat pada Gambar 12.

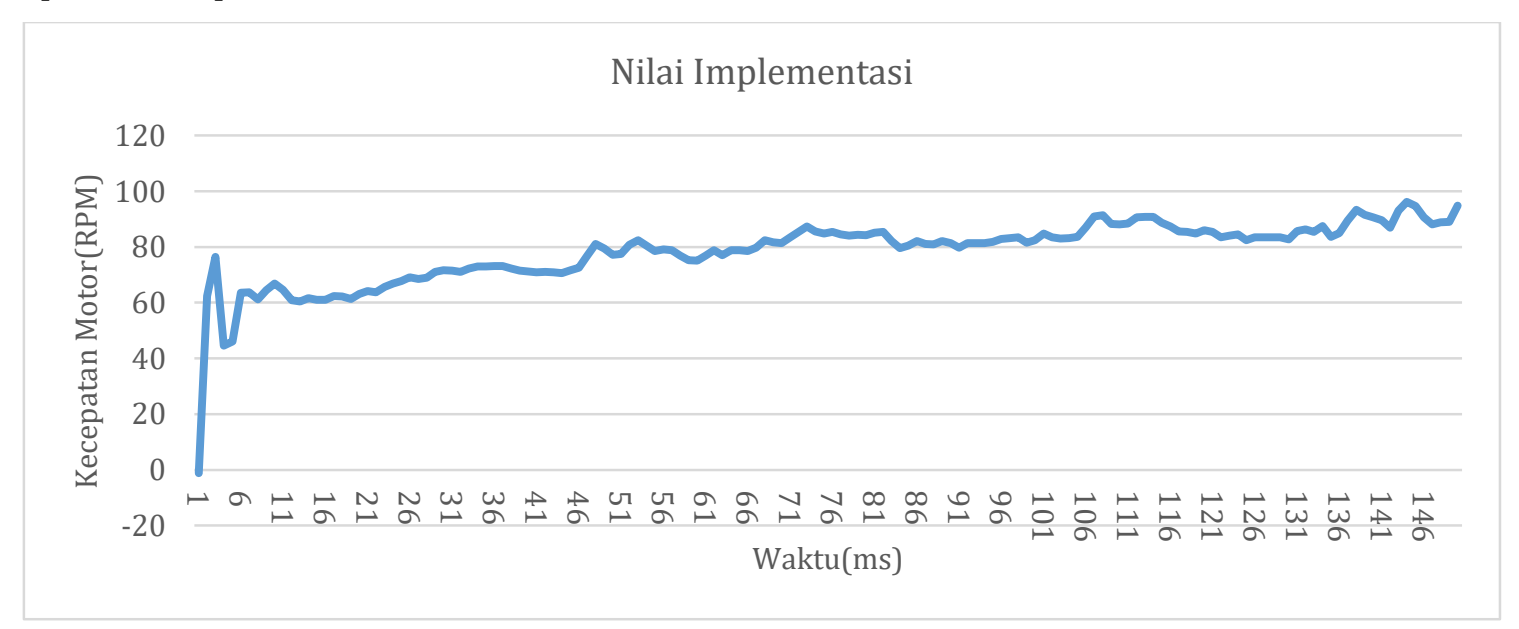

Gambar 12. Respon kendali PID 
Respon yang ditampilkan pada Gambar 12 menunjukkan bahwa respon yang paling sesuai yang dapat diterapkan pada konveyor. Grafik yang ditampilkan pada awal motor dihidupkan menunjukkan nilai RPM hampir menyentuh 80RPM, akan tetapi terjadi undershoot yang menyentuh nilai 40RPM dan setelahnya sistem menjalankan perintah dengan menuju set poin pada 90RPM.

Selanjutnya pengujian tingkat keberhasilan pemisahan, sistem kerjanya yaitu sensor ultrasonik akan membaca beban yang diletakan pada load cell dengan jarak sekian maka akan melakukan perintah kepada servo 1 untuk mengubah sudut guna mendorong beban pada konveyor, kemudian motor servo 2 akan bekerja apabila mendapat perintah dengan beban yang telah ditentukan sehingga akan berubah sudut yang berguna sebagai palang pemisahnya, pengujian sistem di atas telah sesuai dengan yang diharapkan pada penelitian ini, kemudian tingkat keberhasilan pada alat ini dapat dilihat pada Tabel 4.

Tabel 4. Tingkat keberhasilan

\begin{tabular}{cccccc}
\hline \multirow{2}{*}{ No } & Berat & \multicolumn{3}{c}{ Nilai } & Status \\
\cline { 3 - 5 } & Beban & KP & KI & KD & \\
\hline Pengujian 1 & 199,05 & 55 & 20 & 0,0001 & Berhasil \\
\hline Pengujian 2 & 96,39 & 55 & 20 & 0,0001 & Berhasil \\
\hline Pengujian 3 & 152,71 & 55 & 20 & 0,0001 & Gagal \\
\hline Pengujian 4 & 166,01 & 55 & 20 & 0,0001 & Berhasil \\
\hline Pengujian 5 & 98,8 & 55 & 20 & 0,0001 & Berhasil \\
\hline Pengujian 6 & 199,05 & 55 & 20 & 0,0001 & Gagal \\
\hline Pengujian 7 & 96,39 & 55 & 20 & 0,0001 & Berhasil \\
\hline Pengujian 8 & 152,71 & 55 & 20 & 0,0001 & Berhasil \\
\hline Pengujian 9 & 166,01 & 55 & 20 & 0,0001 & Gagal \\
\hline Pengujian 10 & 98,8 & 55 & 20 & 0,0001 & Berhasil \\
\hline Pengujian 11 & 199,05 & 55 & 20 & 0,0001 & Berhasil \\
\hline Pengujian 12 & 96,39 & 55 & 20 & 0,0001 & Berhasil \\
\hline Pengujian 13 & 152,71 & 55 & 20 & 0,0001 & Berhasil \\
\hline Pengujian 14 & 166,01 & 55 & 20 & 0,0001 & Berhasil \\
\hline Pengujian 15 & 98,8 & 55 & 20 & 0,0001 & Berhasil \\
\hline
\end{tabular}

Berdasarkan Tabel 4 tingkat kegagalan terletak pada beban yang harusnya dipisah atau yang lebih dari 100gr, hal ini terjadi karena papan yang digunakan penimbang kurang dekat atau dikarenakan peletakan load cell yang kurang tinggi sehingga sensor ultrasonik terlalu cepat mendeteksi beban atau pendeteksian beban pada ultrasonik terjadi 2 kali sehingga yang dibaca adalah perintah yang terbaru, kemudian kegagalan terjadi dikarenakan permukaan beban yang kurang rata atau terdapat lengkungan-lengkungan yang menyebabkan beban yang akan didorong terhambat, berikut adalah data dari diagram persentase keberhasilannya ditampilkan pada Gambar 13.

\section{Presentase Keberhasilan}

\section{Berhasil}

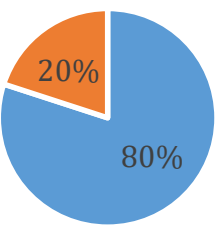

\section{Gagal}

Gambar 13. Persentase keberhasilan 


\section{Kesimpulan}

Berdasarkan penelitian yang berjudul Implementasi Pengendali PID Motor DC Pada Konveyor Pemisah Bibit Kentang Berdasarkan Berat didapat kesimpulan sebagai berikut. Setelah membandingkan hasil pengukuran loadcell dan alat pengukur beban acuan didapat rata-rata nilai error $0,276 \mathrm{gr}$ dengan nilai standar deviasi loadcell 0,211877gr. Nilai yang sesuai untuk digunakan pada implementasi yaitu $\mathrm{KP}=55, \mathrm{KI}=20$ dan $\mathrm{KD}=0,0001$. Persentase keberhasilan pemisah yang didapatkan alat ini yaitu $80 \%$.

\section{Daftar Pustaka}

[1] A. Akhiruddin, "Perancangan Alat Pemisah dan Pensortir Buah Jeruk Berbasis Arduino," J. Electr. $\begin{array}{lllllll}\text { Technol., } & \text { vol. } 2, & \text { no. } & 3, & \text { pp. } & 35-43, & \end{array}$ https://jurnal.uisu.ac.id/index.php/jet/article/view/237

[2] A. A. Fikri and Endryansyah "Sistem Pengaturan PID Motor DC Sebagai Penggerak Mini Conveyor Berbasis Matlab," Jurnal Teknik Elektro, Vol. 8, no. 2, pp. 293-301, 2019. https://jurnalmahasiswa.unesa.ac.id/index.php/JTE/article/view/26947

[3] W. Purbowaskito and C.-H. Hsu, "Sistem Kendali PID untuk Pengendalian Kecepatan Motor Penggerak Unmanned Ground Vehicle untuk Aplikasi Industri Pertanian," J. Infotel, vol. 9, no. 4, p. 376, 2017. https://doi.org/10.20895/infotel.v9i4.253

[4] J. Prasetyo, Purwanto, and Rahmadwati, "Uji Performansi Pada Sistem Kontrol Level Air Dengan Variasi Beban Menggunakan Kontroler PID," J. Mhs. TEUB, vol. 3, no. 17, 2015. http://elektro.studentjournal.ub.ac.id/index.php/teub/article/view/536

[5] M. Nadhif and Suryono, "Aplikasi Fuzzy Logic untuk Pengendali Motor DC Berbasis Mikrokontroler ATMega8535 dengan Sensor Photodioda," J. Tek. Elektro, vol. 7, no. 2, pp. 81-85, 2015. https://journal.unnes.ac.id/nju/index.php/jte/article/view/8594

[6] Z. Jamal, "Implementasi Kendali PID Penalaan Ziegler-Nichols," Jurnal Informatika, vol. 15, no. 1, pp. 81-88,

2015. https://jurnal.darmajaya.ac.id/index.php/JurnalInformatika/article/view/410

[7] M. R. Djalal, H. Nurohmah, A. Imran, and M. Y. Yunus, "Aplikasi Metode Cerdas untuk Optimasi Controller PID Motor DC Berbasis Firefly Algorithm," J. Nas. Tek. Elektro, vol. 6, no. 2, p. 76, 2017. https://doi.org/10.25077/jnte.v6n2.393.2017

[8] R. Birdayansyah, N. Soedjarwanto, and O. Zebua, "Pengendalian Kecepatan Motor DC Menggunakan Perintah Suara Berbasis Mikrokontroler Arduino," Electrician, vol. 9, no. 2, pp. 97-108, 2015. https://electrician.unila.ac.id/index.php/ojs/article/view/168

[9] S. Amalia, "Pengaturan Kecepatan Motor DC Pada Aplikasi Belt Konveyor Menggunakan Logika Fuzzy Berbasis MC," J. Tek. Elektro ITP, vol. 8, no. 1, pp. 5-12, 2019. https://doi.org/10.21063/JTE.2019.3133802

[10] G. Eka, A. Sanjaya, A. Rusdinar, and IG. P. D. Wibawa, "Sistem Pengalihan Arah Conveyor Pada AGV," Skripsi, 2017. https://repository.telkomuniversity.ac.id/pustaka/136707/sistempengalihan-arah-conveyor-pada-agv.html

[11] A. Ma'arif, H. Nabila, Iswanto, and O. Wahyunggoro, "Application of Intelligent Search Algorithms in Proportional-Integral-Derivative Control of Direct-Current Motor System," in The 2019 Conference on Fundamental and Applied Science for Advanced Technology, 2019, vol. 1373, no. 1, pp. 1-10. https://doi.org/10.1088/1742-6596/1373/1/012039

[12] S. F. Anggraini, A. Ma'arif, and R. D. Puriyanto, "Pengendali PID pada Motor DC dan Tuning Menggunakan Metode Differential Evolution (DE)," TELKA - Telekomunikasi Elektronika Komputasi dan Kontrol, vol. 6, no. 2, pp. 147-159, Nov. 2020. https://doi.org/10.15575/telka.v6n2.147159 